\title{
Alpine paleostress reconstruction and active faulting in western Iberia
}

Research Article

\author{
Loreto Antón*, Alfonso Muñoz-Martín, Gerardo De Vicente
}

Grupo de Investigación en Tectonofísica Aplicada,

Departamento de Geodinámica, Facultad CC. Geológicas,

Universidad Complutense de Madrid, Madrid - 28040, Spain

\section{Received 2 March 2010; accepted 26 March 2010}

\begin{abstract}
The study of intraplate tectonics is crucial for understanding the deformation within plates, far from active plate boundaries and associated stress transmission to the plate interiors. This paper examines the tectonic evolution of the Variscan basement at the western margin of the Cenozoic Duero basin. Located east of the Vilariça Fault System in NW Iberia, this intraplate zone is a relatively flat but elevated area with an intense NNE-SSW trending fault system and associated moderate seismicity. Although the area has played an important role in the Duero basin configuration, its Alpine to present-day tectonic evolution has not been well constrained.

In order to characterize the successive paleostress fields, 1428 pairs of fault-striae were measured at 56 sites and two focal mechanisms were used. Stress inversion methods have been applied to analyze paleostress regimes. Results show the existence of three dominant maximum horizontal stress (Shmax) trends: N-S, NE-SW and E-W. Relative and absolute dating of the activated faults for each Shmax shows that the clearly predominant $\mathrm{N}-\mathrm{S}$ paleostress field in the zone has been active since the Oligocene up to the present day; while a NE-SW stress field is found to have been active during the Cretaceous and an older E-W paleostress field was active in the earlier Alpine cycle (Late Triassic).
\end{abstract}

Keywords: stress tensor • fault • paleostress fields • intraplate tectonics • Western Duero Basin • Iberia (C) Versita Warsaw

\section{Introduction}

Within the Eurasian Plate, the stress transmitted from the active margins deformed the intraplate domains and the Variscan basement was included in the Alpine tectonics, forming the main mountain chains. Within the Iberian microplate, as in the rest of the Eurasian Plate, the Variscan basement crops out extensively. Studies dealing with paleostress reconstructions in areas with Mesozoic, Cenozoic

*E-mail: loreant@geo.ucm.es and recent sedimentary rocks are abundant [1-5]. Nevertheless, in extensive intraplate areas where the basement is dominant, only a few studies have attempted to determine the post-Variscan paleostress orientations. The Alpine tectonic evolution, its successive paleostress fields and the contemporary stress field in the central-western Iberia region were thus not well understood. In this paper we present a quantitative analysis of the paleostress patterns from the western Paleozoic margin of the Duero Basin, using fault-slip data inversion methods and propose a reconstruction of the Alpine to present-day stress fields in relation to basement structures.

Located in northwest Iberia, between the Vilariça strike- 
slip deformation belt [6] and the western border of the Cenozoic Duero Basin [7-9], there is a relatively flat but elevated zone (mean elevation of 900 metres above sea level) where the Variscan basement crops out. This area has played an important role in the current configuration of Iberia. It acted as a passive margin for the closed Cenozoic Duero Basin (Figure 1A), and it controls the Atlantic capture and drainage reorientation, acting as a local base level for the inner basin. This is reflected in the area as a convex longitudinal profile of the Duero River; while upstream the river shows a close to equilibrium longitudinal profile (Figure 1B).

Although there is plenty of petrologic and, to a certain extent, structural information about the zone [10-22], little has been published about the tectonic evolution of these faults during Mesozoic and Cenozoic. The main reason is that in Palaeozoic lithologies, it is difficult to determine and to attribute the Late-Variscan and Alpine brittle deformation phases to successive tectonic events and ages. Our goal is to describe the Alpine tectonic evolution of an area where brittle deformation in the Paleozoic basement (responsible for the main fracture pattern) was previously interpreted as post-Variscan.

We have performed a paleostress analysis by means of fault-slip data analysis. Our results indicate the existence of three paleostress fields with dominant maximum horizontal stress (Shmax) trending: N-S, NE-SW and E-W. Owing to the lack of recent sedimentary rocks affected by faults, dating of paleostress fields was carried out using chronological data from the surrounding Cenozoic basin borders and geochronological information obtained from K-Ar dating of clay gouges [23] collected in large faults[24, 25], as well as instrumental seismicity data $[26,27]$. All these data allowed us to establish a chronology of the faulting episodes and to determine the tectonic evolution from Mesozoic to present. The results represent a contribution to our knowledge of the Alpine deformation and the tectonic evolution of the NW Iberia.

\section{Geological setting}

From a geological standpoint, the study area is a crystalline basement developed in a tectonically intricate zone predominantly deformed during the Variscan Orogeny. It belongs to the Central Iberian zone, in the NW sector of the Iberian Massif, and is a part of the largest continuous outcrop of the Variscan Belt $[17,28]$.

The area is far from the Iberian convergent tectonic boundaries (Pyrenees and Betics), and $500 \mathrm{~km}$ east of the western Iberian Atlantic passive margin. Nevertheless, a penetrative NNE-SSW fault system is present and moderate seismicity occurs with earthquake magnitudes $>4[26,29,30]$.

The region was deformed by extensional and strike-slip brittle faulting in post-Variscan and Alpine times. This last brittle deformation is related to the passive margin formation in western lberia during the Triassic and Jurassic [31] and to the far-field effects of the Alpine tectonics in Iberia: convergence at the Northern and Southern borders (Pyrenees and Betics) [4, 32-34]. The Iberian Variscan basement accommodated part of this plate convergence in three E-W trending crustal folds as well as in the reactivation of two left-lateral NNE-SSW strike-slip deformation belts [35]. These NNE-SSW-oriented strike-slip fault systems, the most important of which is the Vilariça fault, are located close to the west of the study area (Figure 1A).

The area shows a clear brittle fault pattern, with a dominant N-S to NE-SW orientation (e.g. Duero, Almendra, Almeida-Valderaduey faults) which is consistent with the large, neotectonically-active fault systems to the west [6, 36-38]. Less important NW-SE trending faults follow the Variscan structure of the area (Figures $1 \mathrm{~A}$ and 2). To the east, the region is limited by the western margin of the Duero Basin. This area shows a weak Alpine deformation in contrast to the Cantabrian and Spanish Central System ranges that form the northern and southern margins of the Duero basin. However, during Paleogene and Neogene times the area was a passive margin with low relief, albeit with a relatively high mean elevation, which accounts for the general lack of sedimentary rocks of that age (Figure 1A).

The fault-slip data used in this study were mainly measured in leucogranites, two-mica and biotite granites to granodiorites and intermediate rocks, except for some data measured on sandstones and conglomerates from Paleocene-Lower Eocene [39] and over a Late Paleocene silicification [40], near the west border of Duero Basin (Figure 2).

\section{Paleostress analysis}

\subsection{Methodology of the fault-slip data anal- ysis}

Methods based on stress-shear relationships have been developed and widely used $[1,5,41,42]$ to quantitatively reconstruct paleostress tensors through inversion of faultslip data. With this aim, fieldwork was oriented towards obtaining the necessary kinematic data from striated fault planes in order to calculate the stress tensors responsible for fault movements. 

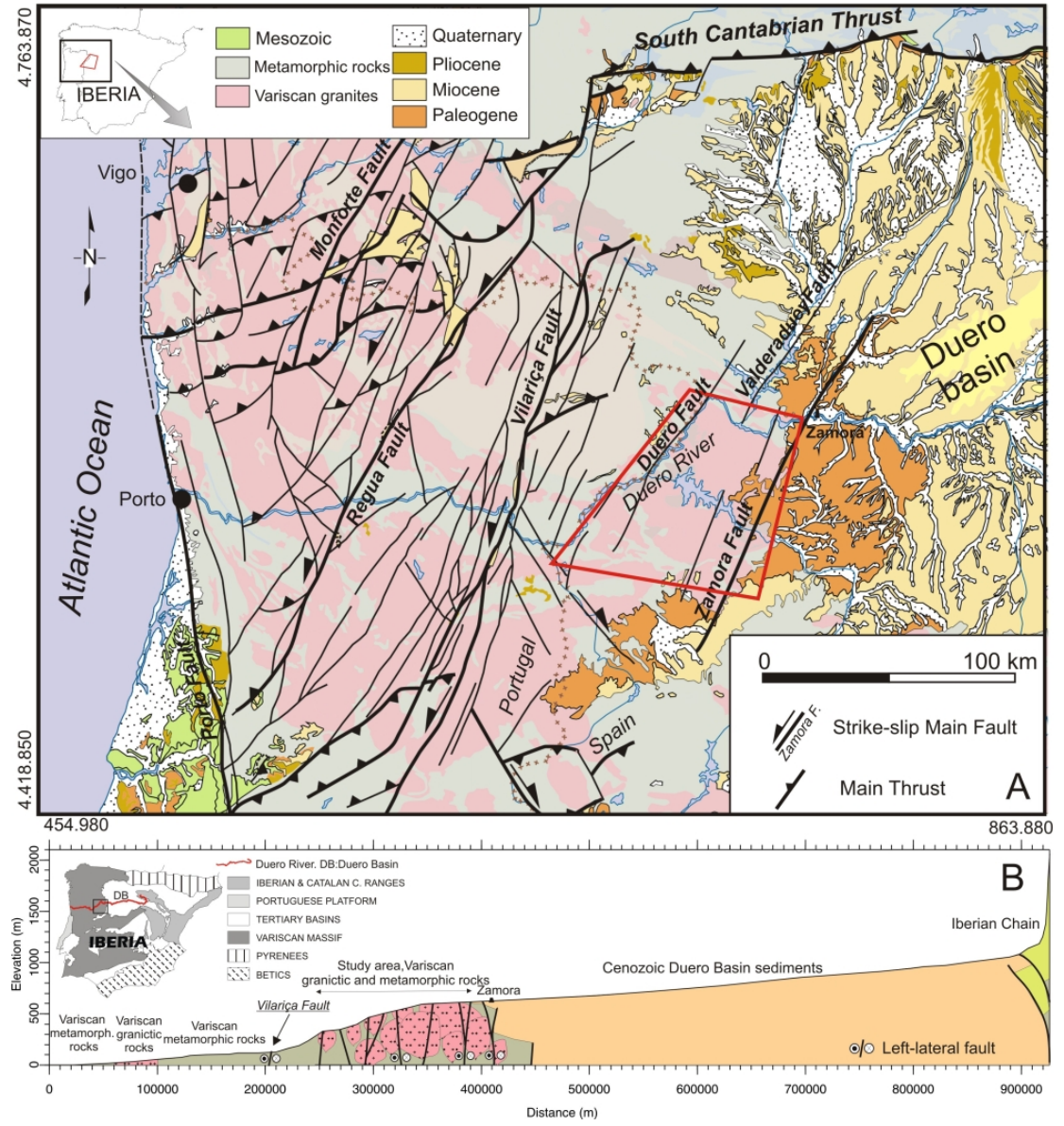

Figure 1. A: Geographical and geological context of the study area, located in central -western Iberia. B: Cross-section sketch of the main geological features along the longitudinal profile of Duero River. Map coordinates in metres (H29UTM).

In the case of polyphase tectonics, the local evidence related to each tectonic event allows a reconstruction of the regionally successive paleostress patterns. The chronology of successive events is deduced in the field using cross-cutting relationships of microstructures or superposition of striae on the same fault plane. With this information, the total fault population from each site is qualitatively divided into different sub-sets, each being consistent with one specific stress regime and showing sequential relationships with the other subsets. Using this information we later analyzed 1428 fault/striae pairs measured at 56 sites. Figure 2 shows the location of the stations on the geological map of the area.

Data analysis was basically performed using the Stress Inversion Method (SIM) developed by Reches [43, 44], though other methods were used to verify the reliability of the results (e.g. Right-Dihedra Method [45]). From the Navier-Coulomb frictional slip criteria and the Bott equation [46], the Stress Inversion Method calculates the best-fitting stress tensor for a large range of friction coefficients $(v)$. Normal $\left(\sigma_{n}\right)$ and shear $(\tau)$ stresses may satisfy the Navier-Coulomb criteria $\left(|\tau|=v \cdot \sigma_{n}\right)$; where $v$ is the friction coefficient. The SIM allows us to determine the orientations of the principal stress axes $\left(\sigma_{1}, \sigma_{2}\right.$, $\left.\sigma_{3}\right)$ and their relative magnitude expressed as the stress ratio, $\mathrm{R}=\left(\sigma_{2}-\sigma_{3}\right) /\left(\sigma_{1}-\sigma_{3}\right)$. $\mathrm{R}$ represents the stress ratio of the ellipsoid, the ratio of stress differences, where $\sigma_{1} \geqslant \sigma_{2} \geqslant \sigma_{3}$ and $1 \geqslant \mathrm{R} \geqslant 0$. The SIM also gives the rock friction and cohesion parameters that occurred when the fault population was active under a specific stress tensor. To estimate the quality of the solution, the method provides two deviation angles: The Principal Axes Misfit Angle (PAM) and the Slip Angular Deviation (SM). PAM is the deviation angle of the principal axes between calculated and ideal tensors while SM indicates the divergence between the slip angle measured in the field (real striae) and the maximum shear stress direction on the slip-plane calculated from the inverted tensor (theoreti- 


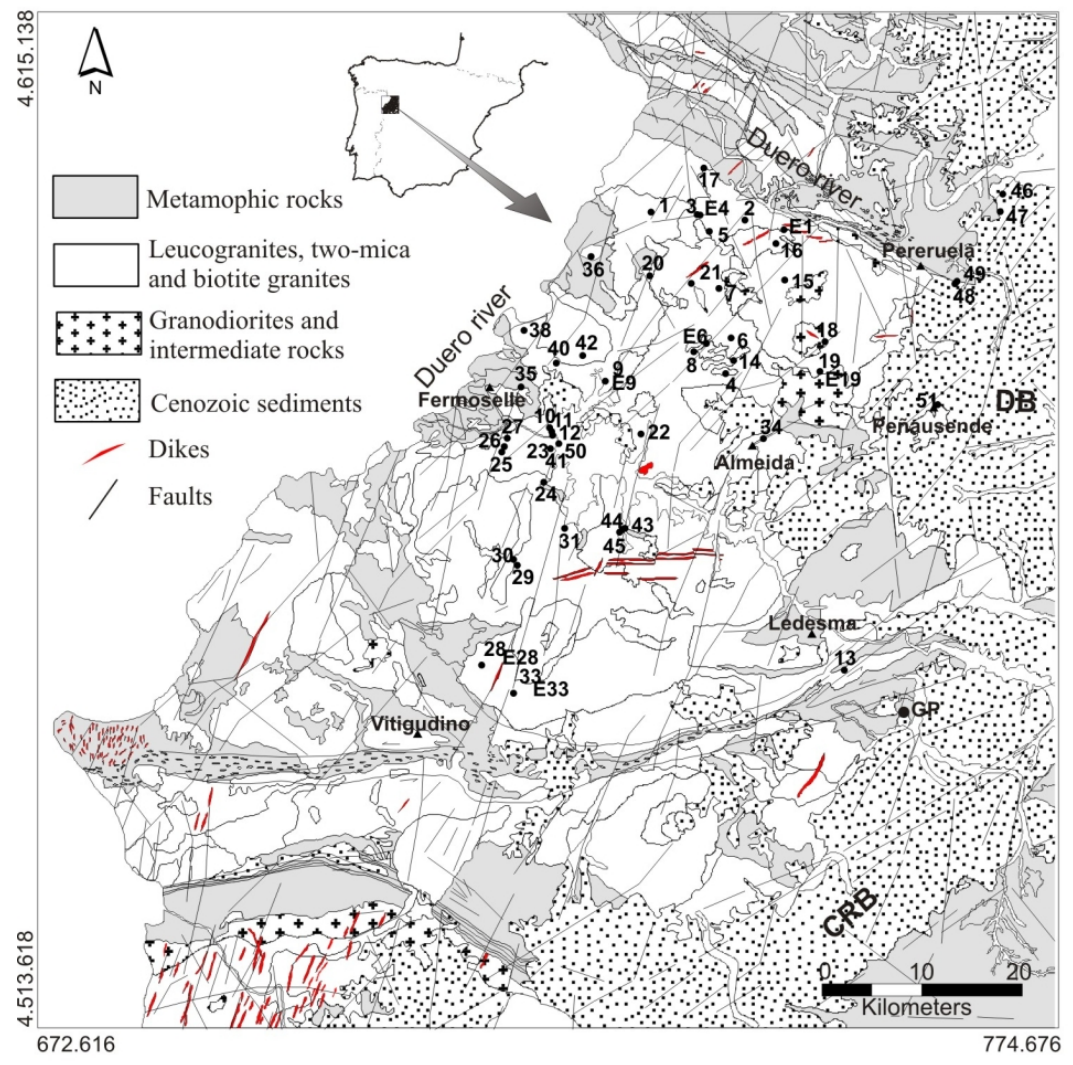

Figure 2. Geological map of the area and location of the studied Sites ( 1 to 51 and E\#). DB: Duero Basin; CRB: Ciudad Rodrigo Basin; GP: Golpejas. Coordinates in metres (H29UTM).

cal striae) $[43,44]$. These values were used as criteria to select the best fit solutions.

Once the best solution and the corresponding friction coefficient are determined, the confidence margins are evaluated here by a Monte Carlo-like technique (sampling with replacement) [47]. The angular deviations of the stress solutions $(\delta \mathrm{A}$, Table 1$)$ are calculated for every fault population [44].

\subsection{Results}

By using this methodology, 65 well-constrained stress tensor solutions explaining 1159 fault/striae pairs were obtained. Table 1 summarizes the stress tensors and orientations obtained from fault-slip data analysis at each measurement site. Once the preliminary results were obtained, all the fault data and stress tensors were analyzed together and then classified into homogeneous subsets; in terms of type and orientation, as well as field observations (relative chronology, e.g. cross-cutting rela- tionships, superposition of striations on fault planes, etc.). The analysis of the 65 tensors obtained revealed a series of convergent solutions clustered together in families with similar principal stress axis trends (Figure 3). After this general view, the Shmax obtained were clustered in three groups, assigned to three possible paleostress fields, with the Shmax oriented N-S, NE-SW and E-W, respectively. It is important to note that, with the exception of data site 49 , all the calculated stress tensors show either a normal faulting or a strike-slip stress regime (Figure 3).

Once the paleostress fields were defined, Shmax trajectory maps were drawn using a distance-weighting method to determine the paleostress direction for any given point within the calculated area [48], taking into account the horizontal error estimation for each Shmax orientation $(\delta A)$. For the different paleostress fields, the mean stress tensor solutions are calculated by analyzing the whole fault population together $[44,45]$.

In terms of the stress orientation, pre-existing crustal structures may play a major role in the accommodation and 
Table 1. Summary of paleostress tensors computed from fault-slip data (sites located in Figure 2). $\sigma_{1}, \sigma_{2}$ and $\sigma_{3}$, orientations of the three main stress axes (trend/plunge, in degrees) $v$, friction coefficient; stress ratio $\mathrm{R}=\left(\sigma_{2}-\sigma_{3}\right) /\left(\sigma_{1}-\sigma_{3}\right) ; \mathrm{N}$ number of fault-slip data used for calculation; $\mathrm{Ne}$, number of explained faults by the stress tensor. $\delta \mathrm{A}$, angular deviations of the stress solutions for each fault population [44].

\begin{tabular}{|c|c|c|c|c|c|c|c|c|}
\hline Site & $\sigma_{1}$ & $\sigma_{2}$ & $\sigma_{3}$ & $\mathrm{n}$ & $\mathrm{R}$ & $\mathrm{N}$ & $\mathrm{Ne}$ & $\mathrm{dA}$ \\
\hline \multirow{2}{*}{1} & 78/155 & $7 / 286$ & $8 / 17$ & 0.3 & 0.84 & \multirow{2}{*}{15} & 7 & 3 \\
\hline & $58 / 21$ & $31 / 199$ & $0 / 290$ & 0.2 & 0.76 & & 8 & 1 \\
\hline E1 & 78/59 & $11 / 223$ & $3 / 314$ & 1.3 & 0.60 & 4 & 4 & 2 \\
\hline \multirow{2}{*}{2} & $82 / 177$ & 7/11 & $1 / 281$ & 0.7 & 0.08 & \multirow{2}{*}{25} & 10 & 16 \\
\hline & 78/89 & $4 / 201$ & $10 / 291$ & 0.3 & 0.58 & & 11 & 9 \\
\hline 3 & $35 / 78$ & $48 / 222$ & $18 / 334$ & 0.2 & 0.71 & 21 & 21 & 1 \\
\hline E4 & $5 / 72$ & 73/180 & $15 / 340$ & 0.9 & 0.54 & 26 & 26 & 6 \\
\hline \multirow{2}{*}{4} & $5 / 31$ & $84 / 189$ & $2 / 300$ & 0.7 & 0.35 & \multirow{2}{*}{13} & 7 & 1 \\
\hline & $24 / 160$ & $60 / 301$ & $16 / 62$ & 0.5 & 0.15 & & 6 & 1 \\
\hline 5 & $52 / 40$ & $34 / 195$ & $12 / 294$ & 0.2 & 0.70 & 19 & 16 & 4 \\
\hline 6 & $39 / 32$ & $49 / 222$ & $4 / 126$ & 0.4 & 0.80 & 12 & 12 & 3 \\
\hline E6 & $18 / 19$ & $69 / 176$ & $7 / 287$ & 0.4 & 0.41 & 13 & 13 & 2 \\
\hline 7 & $49 / 208$ & $40 / 28$ & $0 / 118$ & 0.2 & 0.67 & 20 & 19 & 5 \\
\hline 8 & $67 / 231$ & $22 / 46$ & $2 / 136$ & 0.6 & 0.60 & 22 & 17 & 4 \\
\hline 9 & $83 / 217$ & $3 / 346$ & $4 / 76$ & 0.1 & 0.92 & 58 & 53 & 3 \\
\hline \multirow{2}{*}{ E9 } & 76/77 & $11 / 226$ & $6 / 318$ & 0.3 & 0.45 & \multirow{2}{*}{16} & 7 & 1 \\
\hline & $35 / 341$ & $41 / 212$ & $28 / 94$ & 0.1 & 0.51 & & 9 & 4 \\
\hline 10 & $32 / 175$ & $52 / 28$ & $16 / 275$ & 1.0 & 0.39 & 15 & 11 & 5 \\
\hline 11 & $18 / 28$ & $55 / 269$ & $28 / 128$ & 0.1 & 0.42 & 7 & 7 & 1 \\
\hline 12 & $19 / 176$ & $70 / 351$ & $1 / 86$ & 0.1 & 0.46 & 35 & 31 & 1 \\
\hline 13 & $71 / 149$ & $17 / 351$ & $6 / 259$ & 0.3 & 0.89 & 19 & 13 & 3 \\
\hline 14 & $63 / 353$ & $19 / 217$ & $17 / 121$ & 1.0 & 0.20 & 7 & 6 & 5 \\
\hline 15 & $2 / 187$ & $75 / 87$ & $14 / 278$ & 0.3 & 0.49 & 16 & 16 & 2 \\
\hline 16 & $16 / 217$ & $73 / 34$ & $0 / 126$ & 0.7 & 0.75 & 9 & 9 & 2 \\
\hline \multirow{2}{*}{17} & $88 / 123$ & $0 / 256$ & $1 / 346$ & 0.2 & 0.54 & \multirow{2}{*}{13} & 8 & 1 \\
\hline & $25 / 213$ & $63 / 19$ & $5 / 120$ & 0.9 & 0.40 & & 5 & 5 \\
\hline 18 & $81 / 281$ & $2 / 20$ & $8 / 110$ & 0.4 & 0.26 & 7 & 5 & 3 \\
\hline \multirow{2}{*}{19} & $81 / 299$ & $3 / 184$ & 7/93 & 0.7 & 0.39 & \multirow{2}{*}{67} & 55 & 12 \\
\hline & 73/39 & $16 / 205$ & $4 / 296$ & 0.6 & 0.53 & & 11 & 13 \\
\hline E19 & $2 / 340$ & $84 / 220$ & $4 / 70$ & 0.3 & 0.85 & 28 & 23 & 1 \\
\hline 20 & $45 / 308$ & $44 / 133$ & $2 / 41$ & 0.7 & 0.48 & 4 & 4 & 3 \\
\hline 21 & $2 / 23$ & $75 / 283$ & $14 / 114$ & 0.3 & 0.07 & 79 & 25 & 18 \\
\hline 22 & $66 / 330$ & 20/180 & $10 / 86$ & 0.7 & 0.49 & 7 & 4 & 1 \\
\hline \multirow{2}{*}{23} & $10 / 347$ & $75 / 210$ & $9 / 79$ & 0.3 & 0.63 & \multirow{2}{*}{126} & 75 & 5 \\
\hline & $11 / 88$ & $78 / 248$ & $3 / 357$ & 0.1 & 0.51 & & 24 & 4 \\
\hline 24 & $86 / 224$ & $1 / 5$ & 2/95 & 1.6 & 0.46 & 26 & 26 & 3 \\
\hline 25 & $11 / 188$ & $78 / 10$ & $0 / 278$ & 0.1 & 0.69 & 9 & 9 & 1 \\
\hline 26 & $52 / 229$ & $37 / 50$ & $0 / 320$ & 0.5 & 0.44 & 16 & 14 & 6 \\
\hline \multirow{2}{*}{27} & 24/192 & $62 / 342$ & $12 / 96$ & 0.1 & 0.41 & \multirow{2}{*}{62} & 44 & 4 \\
\hline & $74 / 251$ & $14 / 88$ & $4 / 357$ & 0.2 & 0.56 & & 12 & 6 \\
\hline 28 & $69 / 23$ & 19/181 & $7 / 273$ & 0.2 & 0.73 & 38 & 38 & 9 \\
\hline E28 & $1 / 196$ & $71 / 291$ & $18 / 105$ & 0.2 & 0.17 & 36 & 12 & 1 \\
\hline 29 & $78 / 209$ & $10 / 0$ & $5 / 91$ & 0.9 & 0.49 & 5 & 5 & 3 \\
\hline 30 & $12 / 36$ & $52 / 289$ & $35 / 134$ & 0.2 & 0.59 & 11 & 11 & 1 \\
\hline
\end{tabular}

\begin{tabular}{ccccccccc}
\hline Site & $\sigma_{1}$ & $\sigma_{2}$ & $\sigma_{3}$ & $\mathrm{n}$ & $\mathrm{R}$ & $\mathrm{N}$ & $\mathrm{Ne}$ & $\mathrm{dA}$ \\
\hline \hline 31 & $19 / 263$ & $70 / 81$ & $0 / 172$ & 0.3 & 0.44 & 40 & 23 & 6 \\
\hline 33 & $5 / 354$ & $68 / 100$ & $20 / 262$ & 0.2 & 0.56 & 28 & 28 & 6 \\
\hline E33 & $61 / 253$ & $18 / 19$ & $21 / 117$ & 0.1 & 0.61 & 20 & 12 & 10 \\
\hline 34 & $80 / 70$ & $2 / 176$ & $9 / 267$ & 0.4 & 0.84 & 49 & 49 & 2 \\
\hline \multirow{2}{*}{35} & $66 / 19$ & $23 / 203$ & $1 / 112$ & 0.4 & 0.59 & & 22 & 8 \\
& $73 / 271$ & $13 / 127$ & $9 / 35$ & 0.2 & 0.47 & & 7 & 10 \\
\hline \multirow{2}{*}{36} & $65 / 189$ & $23 / 11$ & $0 / 280$ & 0.3 & 0.77 & 24 & 15 & 4 \\
& $0 / 264$ & $48 / 354$ & $41 / 174$ & 0.9 & 0.08 & & 5 & 2 \\
\hline 38 & $85 / 125$ & $1 / 17$ & $4 / 286$ & 0.1 & 0.77 & 15 & 12 & 3 \\
\hline 40 & $88 / 65$ & $0 / 167$ & $0 / 257$ & 0.1 & 0.59 & 24 & 21 & 4 \\
\hline 41 & $75 / 326$ & $11 / 182$ & $8 / 90$ & 1.1 & 0.71 & 27 & 14 & 1 \\
\hline 42 & $73 / 273$ & $12 / 132$ & $9 / 40$ & 0.1 & 0.43 & 18 & 12 & 1 \\
\hline 43 & $44 / 176$ & $43 / 12$ & $8 / 275$ & 0.7 & 0.63 & 23 & 19 & 8 \\
\hline 44 & $0 / 214$ & $85 / 309$ & $4 / 129$ & 0.5 & 0.53 & 4 & 4 & 2 \\
\hline 45 & $84 / 304$ & $3 / 169$ & $3 / 79$ & 1.0 & 0.48 & 12 & 10 & 1 \\
\hline 46 & $1 / 206$ & $88 / 49$ & $0 / 296$ & 0.1 & 0.69 & 31 & 28 & 6 \\
\hline 47 & $74 / 215$ & $14 / 17$ & $4 / 108$ & 0.3 & 0.32 & 26 & 22 & 10 \\
\hline 48 & $4 / 98$ & $84 / 322$ & $4 / 188$ & 0.2 & 0.17 & 20 & 20 & 6 \\
\hline 49 & $15 / 189$ & 0.0 & $73 / 135$ & 0.2 & 0.62 & 58 & 46 & 15 \\
\hline 50 & $15 / 153$ & $69 / 292$ & $12 / 59$ & 0.7 & 0.54 & 29 & 25 & 17 \\
\hline 51 & $83 / 136$ & $4 / 4$ & $4 / 273$ & 0.8 & 0.12 & 21 & 16 & 5 \\
\hline & & & & & & &
\end{tabular}

nucleation of a later deformation $[2,49]$. The reactivation of pre-existing basement discontinuities produces stress deflections and principal stress axis permutations $[50,51]$. In this sense, the occurrence of extensional and strike-slip stress tensors in the same site is often the result of a local $\sigma_{1}-\sigma_{2}$ permutation, rather than a global tendency of progressive change from one stress regime to another over a short period of time.

The angular variations in Shmax orientations for each paleostress field are small $\left(\delta A<15^{\circ}\right.$, see Table 1$)$ and can be attributed to local small-scale deflections of the regional stress field due to lithological changes or to major fault influence $[49,50,52]$.

Here we should point out that the correspondence between paleostress fields with a common Shmax and major tectonic events is not unequivocal. Relatively important stress trajectory curvatures have been suggested within the Iberian foreland [5] with constrained deformation conditions where the Shmax trends can quickly change over short distances [35]. With this general idea in mind, it is also true that the Iberia interior shows some concentrations of the Shmax trends obtained from paleostress analysis [4].

A brief description of the characteristics of the stress fields and compatible faults is given below. 


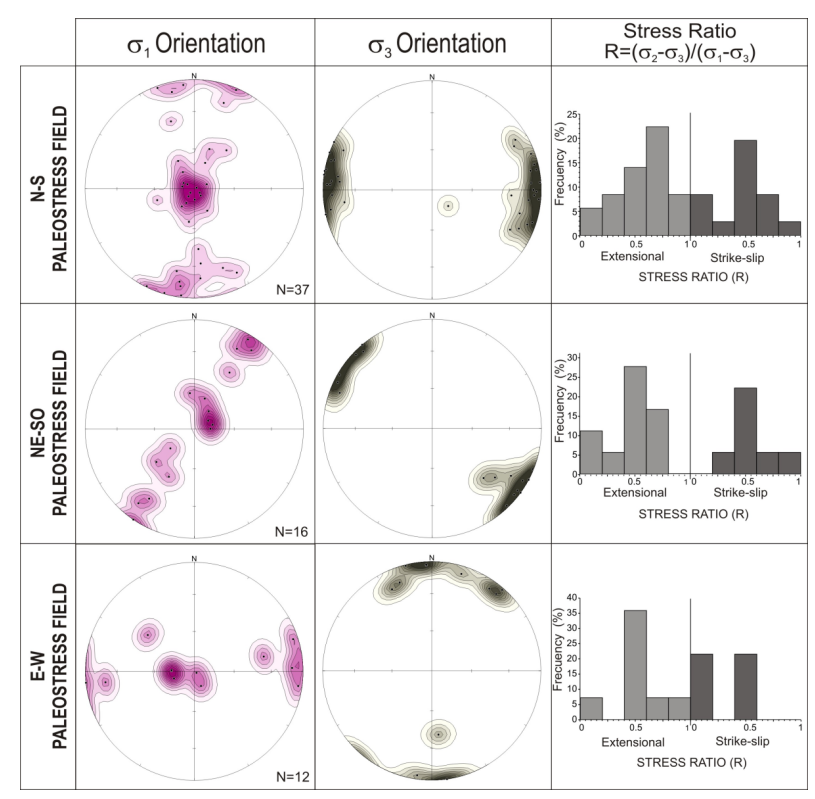

Figure 3. Density stereoplots for $\sigma_{1}$ and $\sigma_{3}$ orientations and stress ratio $(R)$ histograms for the three paleostress fields obtained. Spherical Gaussian contour stereoplot method. $1 \%$ contour intervals represented in lower-hemisphere, equal-area projection.

\subsection{1. $\quad N-S$ paleostress field}

The N-S Shmax paleostress field is the most frequently observed and extends over most of the area, representing $70 \%$ of the explained fault/striae pairs and $57 \%$ of the total calculated stress tensors. It has been identified in 37 of the 56 measurement sites. It has a mean N-S Shmax related to normal and strike-slip faulting and only one reverse stress tensor. The paleostress trajectories [48] are homogeneously N-S oriented.

The mean tensor calculated for this paleostress field, oriented: $\sigma_{1}=179^{\circ} / 76^{\circ}, \sigma_{2}=003^{\circ} / 13^{\circ}, \sigma_{3}=272^{\circ} / 00^{\circ}$, is mechanically compatible with 701 faults out of a total of 999 (Figure 4). The stress ratio (R) of 0.82 supports the idea of the coexistence of normal faulting and strike-slip stress regimes.

Faults explained by the N-S paleostress field are mainly N-S normal faults, NW-SE right-lateral and NE-SW leftlateral strike-slip faults (Figure 4).

\subsubsection{NE-SW paleostress field}

The NE-SW oriented Shmax paleostress field represents only $15 \%$ of the total number of explained fault/striae pairs and $25 \%$ of the calculated stress tensors. It has been identified at 16 sites. With Shmax average orientation of $\mathrm{N} 21^{\circ}-50^{\circ} \mathrm{E}$, it is well represented in the zone with the exception of the south-eastern part, where it was not de- tected. The paleostress map shows a rather homogeneous distribution of the local Shmax axis trends with an average orientation of $\mathrm{N} 40^{\circ} \mathrm{E}$ (Figure 5).

The estimated mean tensor has principal stress axes oriented: $\sigma_{1}=214^{\circ} / 64^{\circ}, \sigma_{2}=034^{\circ} / 25^{\circ}, \sigma_{3}=124^{\circ} / 00^{\circ}$, and explains 152 of the total 181 faults (Figure 5). Once again, a stress ratio $(R)$ of 0.85 points to the coexistence of normal faulting and strike-slip stress regimes.

The compatible faults with the NE-SW paleostress field are normal to oblique-normal and strike-slip faults with NNW to EW trends (Figure 5).

\subsubsection{E-W Paleostress Field}

The E-W paleostress field accounts for $15 \%$ of the faults explained by the inversion analysis and $18 \%$ of the calculated stress tensors. It is found at 12 sites. It is the least represented paleostress field, mostly detected in the western part of the area and, as before, the stress regimes belong to both normal and strike-slip faulting tensors with E-W oriented Shmax (Figure 6).

The estimated mean tensor has principal stress axes oriented: $\sigma_{1}=081^{\circ} / 09^{\circ}, \sigma_{2}=232^{\circ} / 78^{\circ}, \sigma_{3}=350^{\circ} / 05^{\circ}$ and is mechanically compatible with 142 faults out of a total of 204 (Figure 6) and a stress ratio (R) of 0.72.

This paleostress field moved mostly $\mathrm{N} 10^{\circ}-80^{\circ}$ normaloblique and right-lateral strike-slip faults and $\mathrm{N} 90^{\circ}-15^{\circ}$ left-lateral faults (Figure 6).

\subsection{Chronology of the Paleostress fields}

The fact that most of the faults were measured on Variscan granitoid rocks has complicated the estimation of paleostress age from conventional field observations. Complementary dating techniques therefore had to be used. Firstly, a search for relative time markers was carried out beyond the boundaries of the study area, and more specifically in the nearby Cenozoic sedimentary basins (Duero and Ciudad Rodrigo basins; Figure 2). The task was, wherever possible, to search for direct or indirect stratigraphic evidence constraining the timing of fault movement. Furthermore, the complementary dating techniques applied consisted in the collection of fault gouges in order to assess the timing of fault movements by means of $\mathrm{K} / \mathrm{Ar}$ geochronology [23].

Using field data from cross-cutting relationships and superposition of striations on fault planes, we obtained the relative chronology of the successive events. These data indicate that the E-W paleostress field is the oldest one. Cross-cutting indicators of striated fault plane pairs are sparse between the N-S and the NE-SW stress fields. Those observed nevertheless show the N-S paleostress orientation as the latest. On the other hand, sites 46, 47, 


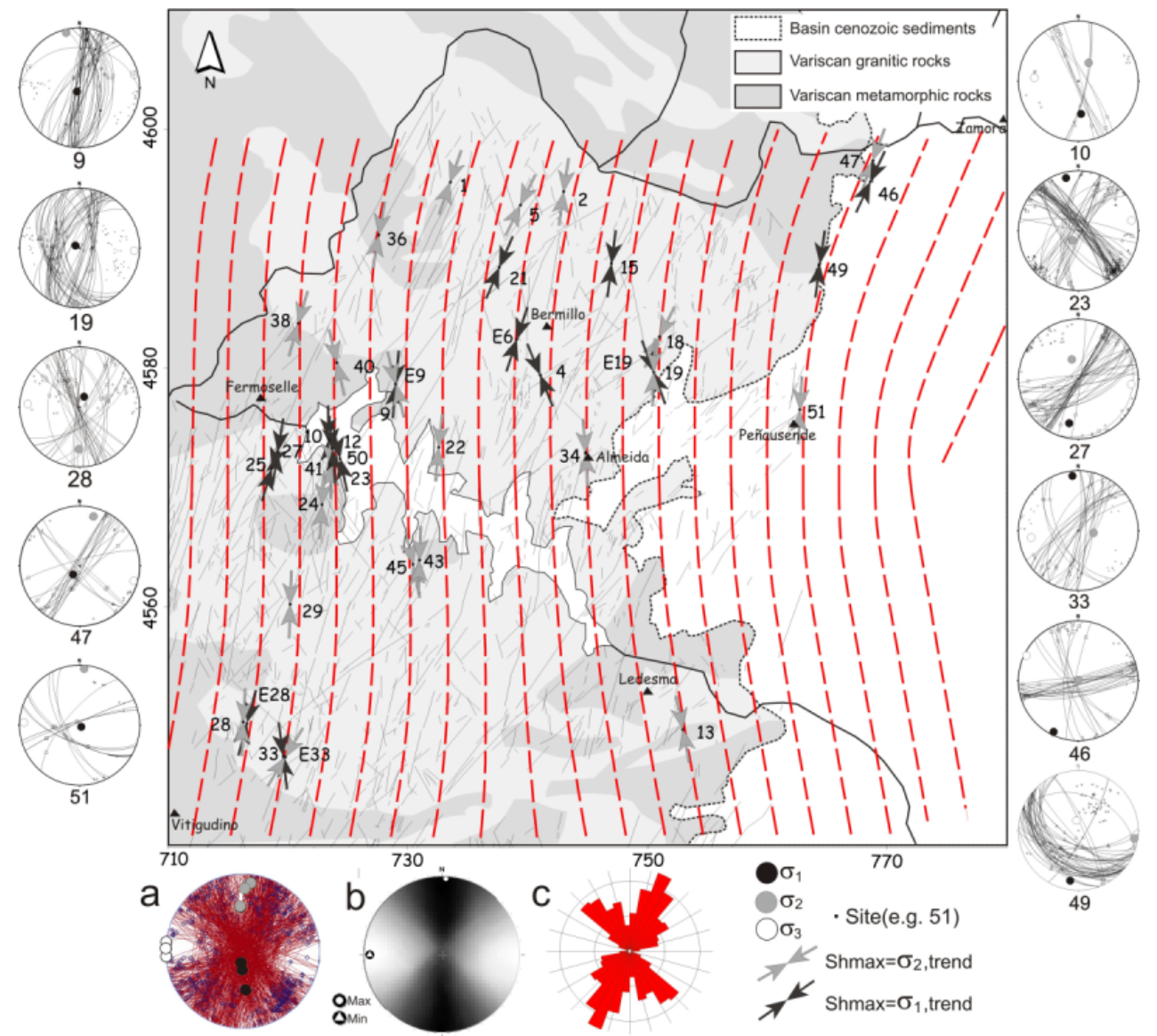

Figure 4. Maximum horizontal stress (Shmax) trajectories map calculated from stress tensor solutions for the N-S paleostress field (Middle Eocene - present day). Mechanically compatible faults are mapped. Examples of fault-slip data and mean tensor solution are shown: (a) explained faults and principal stress axes, b) right-dihedral method solution and c) rose-diagram of compatible faults.

49 and 51 are located at the zone borders and some faultslip data were measured on a Late Paleocene-Eocene silicification [39, 40]. The stress tensors obtained in these sites are related to the $\mathrm{N}-\mathrm{S}$ paleostress field (Table 1, Figure 4).

Systematic analysis of structures affecting the Late Mesozoic deposits and those affecting Cenozoic sediments shows how the former are compatible with the NE-SW Shmax field, while the latter are related to the N-S paleostress field [24]. Other field observations such as faults with a clear Cenozoic activity, e.g. Golpejas fault (Figures 2 and 7) among others, are compatible with a N-S Shmax and structures controlling asymmetries in Quaternary fluvial deposits and lateral migration of valleys are also related with an E-W to ESE-WNW extension [24].

We have complemented these data with absolute dating of fault gouges. Clay samples were collected in fault gouges for dating using the K-Ar technique. At the same time, minor fault slip data were collected within the faults al- lowing us to obtain the corresponding paleostresses. The combination of both results provided useful information for the construction of a possible chronology for the paleostresses. In this sense, ages of $120 \pm 6$ and 86.9 $\pm 4.3 \mathrm{Ma}$ were obtained for clays within structures related to the NE-SW paleostress field, while an age of $210 \pm 11$ Ma was found for clay in a fault gouge related to the E-W paleostress field $[24,25]$. These results agree with the tectonic history shown by some areas of the Iberian Variscan basement, including uplifted zones close to the south, such as the Gredos range in the SpanishPortuguese Central System [53, 54]. These authors, by means of apatite fission track analysis, described accelerated cooling events related to tectonics. Ages obtained $(125 \pm 15 \mathrm{Ma}$ and $88 \pm 12 \mathrm{Ma})$ are equivalent to those revealed by fault gouge dating.

It is important to point out that in this case we have found no evidence of a NW-SE Shmax trending paleostress field. Since this seems to be the most recent orientation of the 


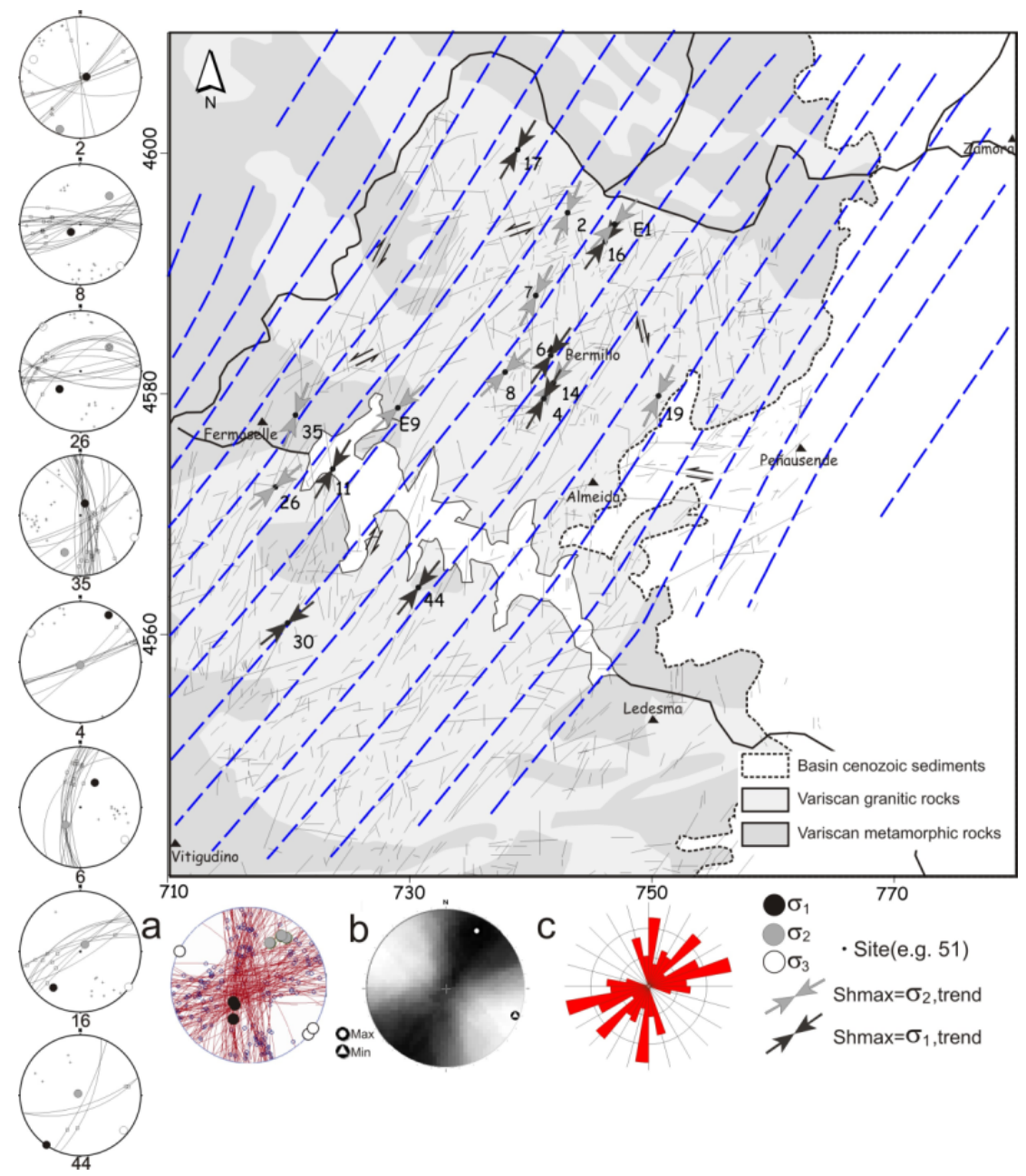

Figure 5. Maximum horizontal stress trajectories map obtained from stress tensor solutions calculated for the NE-SW paleostress field (Cretaceous to Early Cenozoic). Mechanically compatible faults are mapped. Examples of fault-slip data and mean tensor solution are shown: (a) explained faults and principal stress axes, b) right-dihedral method solution and c) rose-diagram of compatible faults.

tectonic stresses within Iberia [30, 41, 55] and also bearing in mind that the NNE-SSW trending Vilariça Fault System shows clear neotectonic activity [6, 37, 38, 56], there are two possible explanations for such a difference. A) The Vilariça Fault system is now moving in transpression, which may imply an important reverse component. B) There is a local rotation in the active Shmax trajectories towards a N-S direction.

Compilation of instrumental seismic activity data for the study area $[26,29]$ provides important information in relation to the moderate active deformation of this intraplate zone and the contemporary tectonic stresses. Two earthquakes occurred during 2003 with magnitudes 3.8 and 4.2 that made it possible to determine well-constrained focal mechanisms [26]. These are typical strike-slip faults with a NNE-SSW trending $\left(N 7^{\circ} \mathrm{E}-\mathrm{N} 12^{\circ} \mathrm{E}\right)$ nodal plane mov- ing under an almost N-S Shmax $\left(\mathrm{N} 2^{\circ}-4^{\circ} \mathrm{E}\right)[24,27]$. From this evidence faults trending close to NNE-SSW direction, like those from the Vilariça Fault System, should still be moving as pure strike-slip faults, compatible with a N-S Shmax.

\section{Discussion and conclusions}

The stress inversion analysis performed on 1428 fault-slip data pairs allowed us to characterize three Shmax trend maxima: N-S, NW-SE and E-W. The estimated stress regimes are mostly extensional to strike-slip.

From the available dating results, it is easy to infer the following sequence of tectonic events. The E-W Shmax trending paleostress is the earliest within a normal to 


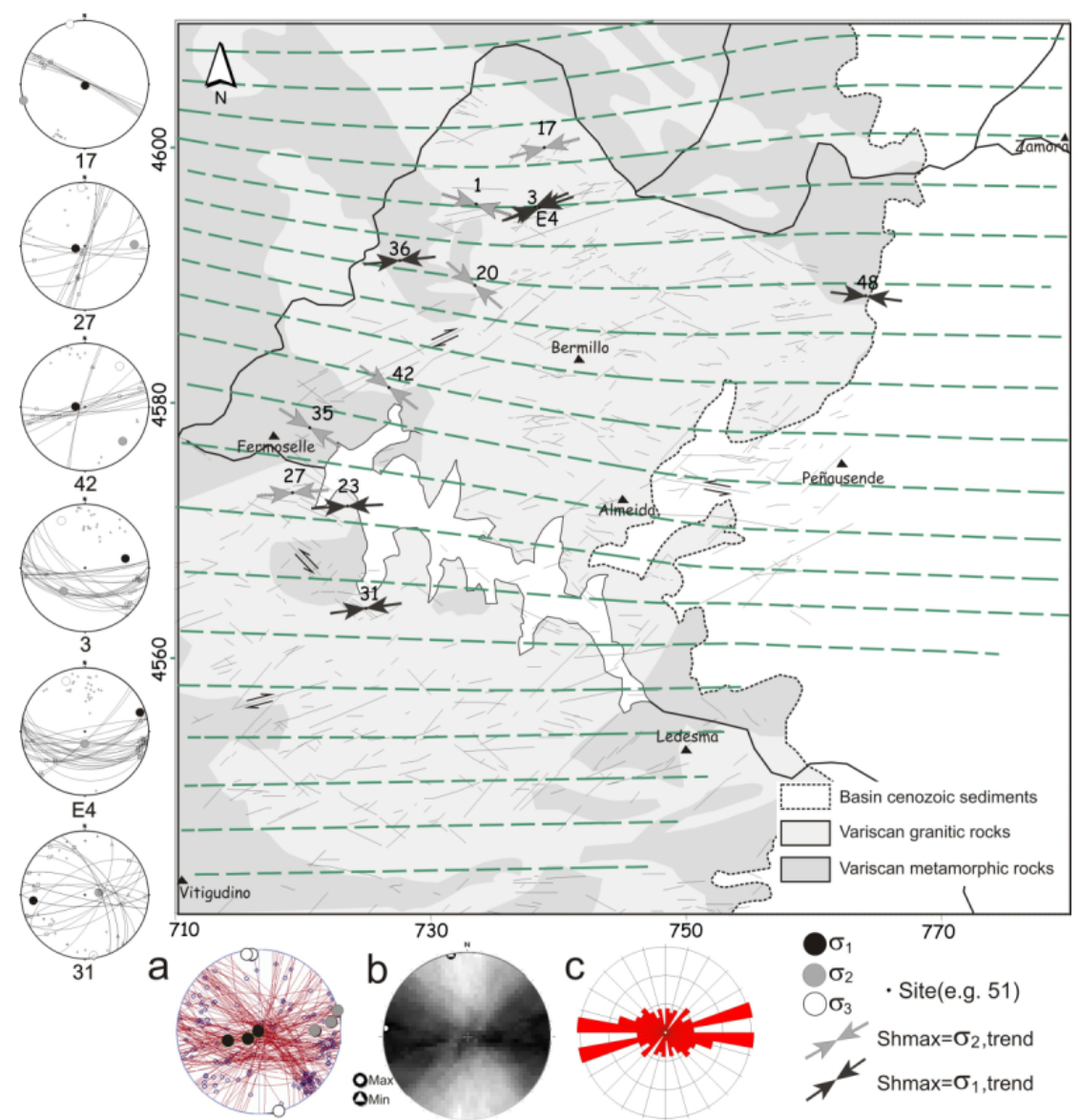

Figure 6. Maximum horizontal stress trajectories map obtained from stress tensor solutions calculated for the E-W paleostress field (Late Triassic). Mechanically compatible faults are mapped. Examples of fault-slip data and mean tensor solution are shown: (a) explained faults and principal stress axes, b) right-dihedral method solution and c) rose-diagram of compatible faults.

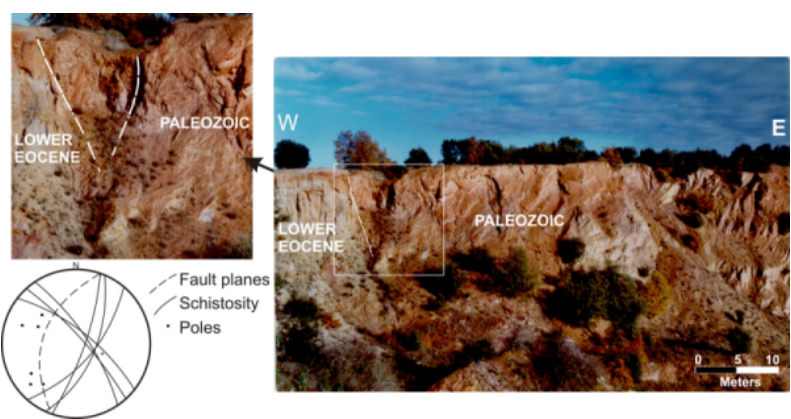

Figure 7. Golpejas fault outcrop showing the tectonic contact between Paleocene sediments and Paleozoic metamorphic rocks. Stereoplot (Wulff net, lower hemisphere) of minor fault planes and schistosity.

strike-slip regime. The second paleostress phase was characterized by the NE-SW trending Shmax (N34 $\left.{ }^{\circ} \mathrm{E}\right)$ and normal to strike-slip faulting. The youngest and most widespread recorded event corresponds to a N-S oriented Shmax which also has a normal to strike-slip stress regime. Regarding the absolute dating results for the fault gouges, the oldest event seems to have occurred during the Late Triassic and the second one in Cretaceous times. Nevertheless, there is also clear evidence of activity of the NE-SW paleostress field during the Cenozoic, as indicated by field data. Finally, field observations support the idea that the $\mathrm{N}-\mathrm{S}$ compression was active from the Middle Paleogene to the Pleistocene, while instrumental seismicity shows this period of activity extending until the present. The first question to be answered is whether the clays from the fault gouges are dating the youngest movements of the faults or only their initial activity; that is, the faults of the NE-SW paleostress field could be Cretaceous in origin, but were also active during Cenozoic under different rheological conditions (not permitting the formation of new clay minerals).

In the tensor analysis, we separated the N-S oriented 
Shmax solutions from those that are NE-SW oriented, even though there is a partial overlap between them in the Shmax solutions and in the orientation of the active faults. This may indicate some kind of relationship between both paleostress fields, since the obtained $R$ value distributions are similar. Therefore, although a single deformation event with local bends can occur close to large strike-slip faults, we can also propose that an anticlockwise rotation in the Shmax trend may have occurred, from the early stages of the Pyrenean foreland deformation (Cretaceous to the Early Paleogene, NE-SW trending) to the most recent ones (probably Oligocene-Miocene, N-S trending).

This N-S paleostress field is registered throughout the Iberian foreland, and is coherent with the tectonic evolution of the Iberia microcontinent during the Cenozoic. Its most likely origin is the collisional processes along the Cantabrian-Pyrenean border $[35,57,58]$. Within the Pyrenean foreland, the Central System (southwards) and the Iberian Chain (eastwards) had experienced the most intense deformation during the Oligocene-Lower Miocene.

The likely presence of this $\mathrm{N}-\mathrm{S}$ paleostress field during the neotectonic period and today may support the idea that the recent NW-SE Shmax related to the Betics has still not been imposed in western lberia [35].

These N-S Cenozoic tectonic stresses and their related faults, in particular the NNE-SSW trending left-lateral strike-slip faults, have controlled the infilling evolution and architecture of the westernmost part of the Duero Cenozoic Basin. Globally, this fault pattern, namely the Vilariça Fault System, seems to change (1) from normal to strike-slip faulting in our study zone, (2) to pure strikeslip close to the Vilariça fault, and (3) to a transpressive regime close to the Atlantic margin.

By comparing our results with those of an intensely studied zone such as the Iberian Chain (e.g. see [4] for a full summary), we can obtain a picture of the different paleostresses acting to the $E$ and $W$ of the less deformed Duero basin during the Cenozoic. By doing so (Figure 8), it is noticeable that the N-S paleostress field is not detected within the Iberian Chain. It seems that the most important event recorded to the $E$ ( 1 and 5 maxima, Figure 8) has apparently undergone a $20^{\circ}$ anticlockwise rotation in our zone $(W)$, where there are almost no solutions resembling the Betic field (Figure 8). Another important difference between these two zones is the presence (Iberian Chain) or absence (W Duero basin) of a thick sedimentary cover. Even though the Iberian Chain presents much more Cenozoic deformation, the simpler sketch obtained to the $W$ may indicate that some of the paleostresses registered to the $E$ are the result of basement-cover accommodation processes, for instance bending along strike-slip faults, rather than real far-field paleostresses.

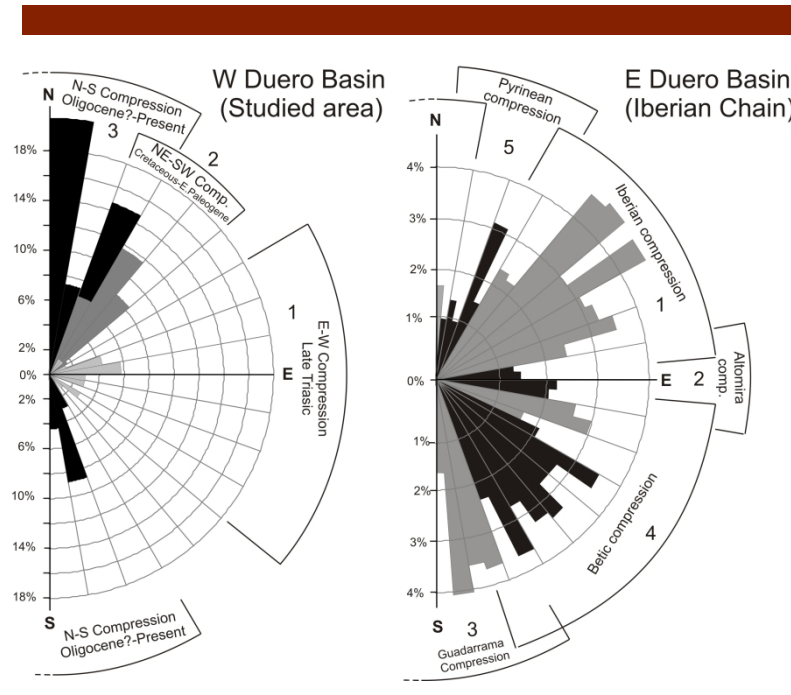

Figure 8. Comparison between stress inversion results represented as rose diagrams of local compression (Shmax) trends for the studied area (NW Duero Basin) and central-east Iberian Chain (from [4])

\section{Acknowledgements}

This study was supported by Consolider Ingenio 2006: "Topoiberia" (CSD2006-00041) and the Spanish National Research Program: "Topoiberia Foreland" (CGL200613926-C02-01-02). Valuable and constructive comments by Alfred Lacazette and anonymous reviewers are gratefully acknowledged.

\section{References}

[1] Bergerat F., Stress field in the European plataform at the time of Africa-Eurasia collision, Tectonics, 1987, 6, 99-132

[2] Homberg C., Bergerat F., Philippe Y., Lacombe O., Angelier J., Structural inheritance and Cenozoic stress fields in the Jura fold-and-thrust belt (France), Tectonophysics, 2002, 357, 137-158

[3] Lamarche J., Bergerat F., Lewandovski M., Mansy J.L., Świdrowska Y., Wieczorek J., Variscan to Alpine heterogeneous paleo-stress field above a Major Palaeozoic suture in the Carpathian foreland (southeastern Poland), Tectonophysics, 2002, 357, 55-80

[4] Liesa C.L., Simón J.L., Evolution of intraplate stress fields under multiple remote compressions: The case of the Iberian Chain (NE Spain), Tectonophysics, 2009, 474, 144-159, doi:10.1016/j.tecto.2009.02.002

[5] Muñoz Martín A., Cloetingh S., De Vicente G., Andeweg B., Finite-element modelling of Tertiary paleostress fields in the eastern part of the Tajo Basin 
(central Spain), Tectonophysics, 1998, 300, 47-62

[6] Cabral J., An example of intraplate neotectonics activity, Vilariça basisn, northeast Portugal, Tectonics, 1989, 8, 285-303

[7] Santisteban J. I., Mediavilla R., Martín-Serrano A., Dabrio C.J., The Duero Basin: a general overview. In: Friend P.F., Dabrio C.J. (Eds.), Tertiary basins of Spain: the stratigraphic record of crustal kinematics, Cambridge Univ. Press, Cambridge, 1996, 183-187

[8] Armenteros I., Corrochano A., Alonso-Gavilán G., Carballeira J., Rodríguez J.M., 2002. Duero basin (northern Spain). In: Gibbons W., Moreno T. (Eds.), Geology of Spain. Geol. Soc., London, 2002, 309-315

[9] Alonso-Gavilán G., Armenteros I., Carballeira J., Corrochano A., Huerta P., Rodríguez J.M., Cuenca del Duero. In: Vera J.A. (Ed.), Geología de España. Soc. Geol. España. IGME, Madrid, 2004, 550-556

[10] Martínez Fernández F.J., Estudio del área metamórfica y granítica de los Arribes del Duero (Provincias de Salamanca y Zamora), PhD thesis, Universidad de Salamanca, 1974

[11] Martínez Fernández F.J., Données sur le métamorphisme régional hercynien dans le Dôme du Tormes, Geologische Rundschau, 1977, 66, 91-98

[12] Arthaud F., Matte Ph., Les décrochements TardiHercyniens du Sud-ouest de l'Europe. Géometrie et essai de reconstitution des conditions de la déformation, Tectonophysics 1975, 25, 139-171

[13] Arthaud F., Matte P., Late Paleozoic strike-slip faulting in southern Europe and northern Africa: Result of a right-lateral shear zone between Appalachians and the Urals, Geol. Soc. Am. Bull., 1977, 88, 1305-1320

[14] Iglesias M., Choukroune P., Shear zones in the Iberian Arc, J. Struct. Geol., 1980, 2, 63-68

[15] Iglesias M., Ribeiro A., Zones de cisaillament ductile dans l'arc ibero-armoricain, Comunicaçoes dos Serviços Geológicos de Portugal, 1981, 67, 85-87

[16] López Plaza M., Carnicero A., El plutonismos hercínico de la penillanura Salamantino-Zamorana (centro-oeste de España): Visión de conjunto en el contexto geológico regional. In: Bea F., Carnicero A., Gonzalo J. C., López Plaza M., Rodríguez Alonso M. D. (Eds.), Geología de los granitoides y rocas asociadas del Macizo Héspérico, Rueda, 1987, 53-68

[17] Díez Balda M.A., Vegas R., Gonzalez Lodeiro F., Central Iberian Zone: Structure. In: Dallmeyer R.D., Martínez García E., (Eds.), Pre-Mesozoic Geology of Iberia, Springer-Verlag, Berlin, 1990, 172-188

[18] García de Figuerola L. C., Rodríguez Alonso M. D., Carnicero A., Pellitero E., Murciego A., Navarrete J., López Plaza H., Franco P., Gonzalo J.C., Geología regional y mineralizaciones del dominio Hercínico del centro-oeste español. Sociedad Geológica España, 1992, 49-62

[19] Villar Alonso P., Escuder Viruete J., Martínez Catalán J. R., La zona de Cizalla de Juzbado-Peñalba do Castelo en el sector español. Actas del Congreso Latinoamericano de GeologÃळa, 1992, 8, 446-456

[20] López Plaza M., Gonzalo J. C., Caracterización geoquímica de las anatexitas del Domo del Tormes (provincias de Salamanca y Zamora), Revista de la Sociedad Geológica de España, 1993, 6, 113-128

[21] Ares Yáñez M., Gutiérrez Alonso G., Díez Balda M. A., Álvarez F., La prolongación del despegue de Salamanca (segunda fase de deformación varisca) en el Horst de Mirueña (Zona Centro Ibérica), Revista de la Sociedad Geologica de España, 1995, 8, 171-191

[22] Santisteban J.I.; Martín Serrano A., Mediavilla R. Y., Dabrio C. J., South-western Duero and Ciudad Rodrigo basins: infill and dissection of a Tertiary basin. In: Friend P.F., Dabrio C.J. (Eds.), Tertiary basins of Spain: the stratigraphic record of crustal kinematics. Cambridge Univ. Press, Cambridge, 1996, 196-202

[23] Vrolijk P.Y, Van der Pluijm B.A., Clay Gouge, J. Struct. Geol., 1999, 21, 1039-1048

[24] Antón L., Análisis de la fracturación en un área granítica intraplaca: El Domo del Tormes, PhD thesis, Universidad Complutense de Madrid, Spain, 2003

[25] Antón L., Muñoz Martín A., De Vicente G., Galindo C., Datación de eventos tectónicos mediante integración de geocronología K-Ar y análisis de paleoesfuerzos en el Domo del Tormes. Geotemas (Madrid), 6, Vol. 1, 173-176

[26] Stich D., Ammon C.J., Morales J., Moment tensor solutions for small and moderate earthquakes in the Ibero-Maghreb region, J. Geophys. Res., 2003, 108, 02JB00205

[27] Antón L., De Vicente G., Tensor actual de esfuerzos y fallas potencialmente activas en el Domo del Tormes (NO de Iberia), 2006, Geogaceta 40, 11-14

[28] Julivert M., Fontboté J., Ribeiro A. Y, Navais Conde L. E., Mapa Tectónico de la Península Ibérica y Baleares. Escala 1/1.000.000. Instituto Geológico y Minero de España (IGME), Madrid, 1972

[29] IGN, http://www.ign.es/ign/es/IGN/SisCatalogo.jsp

[30] De Vicente G., Cloetingh S., Munoz Martin A., Oláiz A., Stich D., Vegas R., Galindo-Zaldívar J., FernándezLozano J., Inversion of moment tensor focal mechanisms for active stresses around the microcontinent iberia; tectonic implications, Tectonics, 2008, 27 TC1009

[31] Srivastava S. P., Roest W. R., Kovacs L. C., Oakey G., Levesque S., Verhoef J., et al. Motion of Iberia since the Late Jurassic; results from detailed aero- 
magnetic measurements in the Newfoundland Basin; Alpine evolution of Iberia and its continental margins, Tectonophysics, 1990, 184, 229-260

[32] Andeweg B., de Vicente G., Cloetingh S., Giner J., Munoz Martin A., Local stress fields and intraplate deformation of iberia; variations in spatial and temporal interplay of regional stress sources; tectonics of continental interiors, Tectonophysics, 1999, 305, 153164

[33] Galindo-Zaldivar J., Gonzalez-Lodeiro F., Jabaloy A., Stress and palaeostress in the Betic-rif cordilleras (Miocene to the present), Tectonophysics, 1993, 227, 105-126

[34] Galindo Zaldivar J., Jabaloy A., Serrano I., Morales J., Gonzalez Lodeiro F., Torcal F., Recent and presentday stresses in the Granada basin (Betic Cordilleras); example of a Late Miocene-present-day extensional basin in a convergent plate boundary, Tectonics, 1999, 18, 686-702

[35] De Vicente G., Vegas R., Large-scale distributed deformation controlled topography along the western Africa-Eurasia limit: Tectonic constrains, Tectonophysics, 2009, 474, 124-143

[36] Cabral J., Ribeiro A., Neotectonic studies in Portugal - the neotectonic Map, Bull. INQUA, 1990

[37] Ribeiro A., Baptista N., Cabral J., Matias L., Tectonic stress pattern in Portugal mainland and the adjacent Atlantic region (West Iberia), Tectonics, 1996, 15, 641-659

[38] Rockwell T., Fonseca J., Madden C., Dawson T., Owen L., Vilanova S., Figueiredo P., Paleoseismology of the Vilariça Segment of the Manteigas-Bragança Fault in Northeastern Portugal. Geological Society, London, Special Publications, 2009, 316, 237-258

[39] Santisteban J.I., Martín-Serrano A., Mediavilla R., El Paleógeno del Sector suroccidental de la cuenca del Duero: Nueva división estratigráfica y controles sobre su sedimentación. In: Colombo F. (ed.). Libro Homenaje a Oriol Riba. (Cuencas Terciarias de España), Acta Geológica Hispánica, 1991, 26, 133-148

[40] Blanco J.A., Corrochano A., Montigny R., Thuizat R., Sur l'age du debut de la sedimentation dans le bassin tertiaire du Duero (Espagne). Atribution au Paléocène par datation isotopique des alunites del'unité inferieure, Comptes Rendus de l'Acade'mie des Sciences Paris, 1982, 295, 559-562

[41] De Vicente G., Giner J., Muñoz-Martín A., GonzálezCasado J.M., Lindo R., Determination of present-day stress tensor and neotectonic interval in the Spanish Central System and Madrid Basin, central Spain, Tectonophysics, 1996, 266, 405-424

[42] Bergerat F. Angelier J., Andreasson P., Evolution of paleostress fields and brittle deformation of the Tornquist Zone in Scania (Sweden) during PermoMesozoic and Cenozoic times, Tectonophysics, 2007, 444, 93-110

[43] Reches Z., Detemination of the tectonic stress tensor from slip along faults that obey the Coulomb yield condition, Tectonics, 1987, 7, 849-861

[44] Reches Z., Baer G., Hatzor Y., Constraints on the strength of the upper crust from stress inversion of fault slip data, J. Geophys. Res., 1992, 97, 1248112493

[45] Angelier J., Mechler P., Sur une metode graphique de recherche des contraintes principales egalement utilisable en tectonique et en seismologie: la methode des diedres droites, B. Soc. Geol. Fr, 1977, 7, 13091318

[46] Bott M.H.P., The mechanism of oblique-slip faulting, Geol. Mag., 1959, 96, 109-117

[47] Stuart A., The Ideas of Sampling, C. Griffin, High Wycombe, 1984

[48] Lee J.C., Angelier J., Paleostres trajectory maps based on the results of local determinations: the "lissage" program, Computers and Geosciences, 1994, 20, 161191

[49] Homberg C., Hu J.C., Angelier J., Bergerat F., Lacombe O., Characterization of stress perturbations near major fault zones: Insights from 2-D distinct-element numerical modeling and field studies (Jura Mountains), J. Struct. Geol., 1997, 19, 703-718

[50] Rebaï S., Philip H., Taboada A., Modern tectonic stress field in the Mediterranean region: evidence for variation in stress directions at different scales, Geophys. J. Int., 1992, 110, 106-140

[51] Oláiz A.J., Muñoz-Martín A., De Vicente G., Vegas R., Cloetingh S., European continuous active tectonic strain-stress map, Tectonophysics, 2009, 474, 33-40

[52] Rawnsley K.D., Rives T., Petit J.P., Joint development in perturbed stress fields near faults, J. Struct. Geol., 1992, 14, 939-951

[53] De Bruijne C. H., Andriessen P. A. M., Interplay of intraplate tectonics and surface processes in the sierra de Guadarrama (central Spain) assessed by apatite fission track analysis; erosion and tectonic movements; from measurements to physical modelling. Physics and Chemistry of the Earth.Part A, Solid Earth and Geodesy, 2000, 25, 555-563

[54] De Bruijne C.H., Andriessen P.A.M., Far field effects of Alpine plate tectonism in the Iberian Microplate recorded by fault-related denudation in the Spanish Central System; Low temperature thermochronology; from tectonics to landscape evolution, Tectonophysics,2002, 349, 161-184 
[55] Herráiz M., De Vicente G., Lindo-Ñaupari R., Giner J., Simón J.L., González Casado J.M., Vadillo O., Rodríguez Pascua M.A., at al, The recent (upper Miocene to Quaternary) and present tectonic stress distributions in the Iberian Peninsula, Tectonics, 2000, 19, 762-786

[56] Moreira V.S., Seismotectonics of Portugal and its adjacent area in the Atlantic, Tectonophysics, 1985, 117, 85-96

[57] Ferrus B., Santanach P., Analisis de la fracturacion en la cuenca cenozoica de As Pontes (La Coruna), Geogaceta, 1994, 15, 147-149

[58] Santanach Prat P., Las cuencas terciarias gallegas en la terminacion occidental de los relieves pirenaicos, Cuad. Lab. Xeolo. Laxe, 1994, 19, 57-71 